\title{
タンパク質と塩素との水中に括ける反応による 有機塩素化合物の生成
}

Formation of organic chlorides at the reaction of proteins in water with chlorine.

$\begin{array}{ccc}\text { 名 川 吉 信, } & \text { 植 松 喜 稔, } & \text { 西 } \text { 末 雄 } \\ \text { Yoshinobu NAGAWA } & \text { Kitoshi UEMATSU } & \text { Sueo NISHI }\end{array}$

\begin{abstract}
The reactions of proteins and their major constituent amino acids with chlorine in water have been studied and the following results are obtained.

1) Proteins have the potential properties of yielding chloroform or total organic chloride (TOCl) as similar extent to humic acid.

2) At the $\mathrm{pH}$ range of $4-10$, the amounts of chloroform formed from proteins increase with increasing $\mathrm{pH}$, whereas the yields of $\mathrm{TOCl}$ show maxima at $\mathrm{pH}$ 8.5. In the cases of amino acids, the amounts of chloroform and $\mathrm{TOCl}$ formed vary depending on the kinds of amino acids. However, the $\mathrm{pH}$ dependencies in the chloroform formations from amino acids and in the TOCl formations from certain amino acids which yield higher levels of $\mathrm{TOCl}$ are similar to those in the cases of proteins.

3) The amounts of chloroform and $\mathrm{TOCl}$ formed from proteins can be expressed as the following equation. $[\mathrm{OCl}]=\mathrm{K}[\mathrm{P}][\mathrm{Cl}]^{\mathrm{m}} \mathrm{t}^{\mathrm{n}}$
\end{abstract}

Where $[\mathrm{OCl}]$ is the concentration of chloroform or $\mathrm{TOCl},[\mathrm{P}]$ is the concentration of protein, $[\mathrm{Cl}]$ is the concentration of chlorine, and $\mathrm{K}, \mathrm{m}$, and $\mathrm{n}$ are the parameter.

KEY WORDS : chlorination, protein, amino acid, chloroform, total organic chloride

\section{1.緒言}

水道の塩素処理過程に执いて，トリハロメタンなど の有機ハロゲン化合物を生成するといらことが良く知 られており，それらを生ずるような前駆物質と塩素と の反応が盛んに研究されている1”。前駆物質としては, フミン酸が主要なものと考光られてきだが，最近で は, ᄂ尿処理水 ${ }^{3)}$, 藻類ならびにその代謝物 ${ }^{4) \sim 6) か ゙ ト リ ~}$ 八ロメタンを多く生成することが報告されている。

ところで, 有機物質と塩素の反応を行らと,トリハ ロメタンだけでなく，さまざまな有機ハロゲン化合物 を生成する7゙。のような有機ハロゲン化合物を総量と してとらえる考觉占があり，その目的のための装置も市 販されている。
ここでは，有機ハロゲン化合物を生成する前駆物質 の研究の一環として，6種類のタンパク質と塩素の希 薄水溶液中に打梳る反応を行い, 全有機塩素 $(\mathrm{TOCl})$ 量, 揮発性有機塩素 $(\mathrm{POCl})$ 量扒よびクロロホルム生 成量を検討した。また，タンパク質の主要な構成要素 であるアミノ酸と塩素の反応について，有機塩素化合 物の生成の観点から検討した報告は比較的少なく 11),アミノ酸の種類も限られている。そこで, タンパク 質中に通常見られる22種類のアミノ酸について, タン パク質と塩素の反応と同様の検討を行なった。その結 果，有用な知見を得たので報告する。

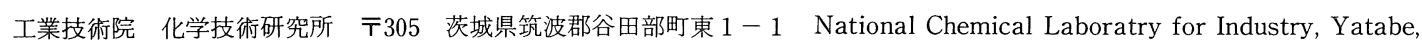

Tsukubagun, Ibaraki 305 Japan 


\section{2. 実験}

\section{1 試料}

塩素は高度さらし粉と塩酸により発生させたガスを 冷水中に溶解させ, 約 $4 \mathrm{~g} / 1$ の水溶液を調製した。塩 素水溶液は共栓付褐色瓶に入れ冷蔵庫中に保存し, 使 用する直前にヨウ素滴定により濃度を測定し，適当に 希釈して反応に用いた。

タンパク質扣よびオリゴペプチドはシグマ社製を用 い,システインとグルタミンは関東化学製特級試薬を, それら以外のアミノ酸は宝興産製 $\mathrm{A}$ 規格のものを用 いた。その他の試薬は市販の特級試薬を用いた。

塩素水の調製および反応に使用した水は, イオン交 換水を蒸留することによって調製した。

\section{2 反応}

タンパク質またはアミノ酸水溶液, リン酸塩緩衝液, 塩素水溶液を内容積 $120 \mathrm{ml}$ のアルミシールバイアルに 溶液量 $100 \mathrm{ml}$ となるように入れ, 直ちにテフロンフィ ルム, シリコンゴムで密栓した。 $20^{\circ} \mathrm{C}$ の恒温槽中に所 定時間放置後, 亜硫酸ナトリウム水溶液を注入して反 応を停止し，分析を行った。

なお，特に断わらない限り，タンパク質执よびアミ ノ酸水溶液の濃度は $10 \mathrm{mg} / 1$, 塩素水溶液の濃度は20 $\mathrm{mg} / 1$, 反応時間は24時間とした。

\section{3 分 析}

ヘッドスペースーガスクロマトグラフ法により, ク ロロホルムの生成量を求めた。ガスクロマトグラフの 測定条件は次のと拈りとした。

装置: 島津製 $\mathrm{GC}-4 \mathrm{CM}$ 型, 検出器 : $\operatorname{ECD}\left({ }^{63} \mathrm{Ni}\right)$, 充填剤: $20 \%$ Silicone DC550, カラム温度 : $90^{\circ} \mathrm{C}$, その後, 上記と同一溶液中の $\mathrm{POCl}$ 执よび $\mathrm{TOCl}$ を 三菱化成製全有機ハロゲン分析装置 TOX - 10 型を用 いて測定した。 $\mathrm{POCl}$ は試料を $50^{\circ} \mathrm{C}$ 加熱したパージ 管に注入し, 酸素 $150 \mathrm{ml} / \mathrm{min}$ で 5 分間バブリングし, パージされた $\mathrm{POCl}$ を $850^{\circ} \mathrm{C}$ に加熱した燃焼管に導き, 塩化水素に変換して銀イオンによる電量滴定で定量し
た。TOCl は活性炭80mg を充填したカラム中に硝酸酸 性にした試料を $3 \mathrm{ml} / \mathrm{min}$ の速度で通液して有機塩 素化合物を吸着させ, 硝酸カリウム水溶液で洗浄して 吸着した塩化物イオンを除去後, 活性炭を燃焼管に入 れ $\mathrm{POCl}$ と同様に定量した。 POCl および TOCl は塩 素換算值として表した。吸着に用いた活性炭のブラン ク値などを考慮して，定量下限を $\mathrm{TOCl}$ で $10 \mu \mathrm{g} / 1$, $\mathrm{POCl}$ とクロロホルムで $5 \mu \mathrm{g} / 1$ とした。なお,プラン ク操作による有機塩素化合物の生成量はこれらの值以 下であった。

\section{3.結果および考察 \\ 3.1 中性域での反応}

$\mathrm{pH} 7$ に扣ける塩素と 6 種類のタンパク質の反応に よって生成した有機塩素化合物の $\mathrm{TOCl}, \mathrm{POCl}$, 执よ びクロロホルムの測定值を Table 1 に示した。クロロ ホルム生成量は77〜 $170 \mu \mathrm{g} / 1$ の範聿にあり, タンパク 質の種類によってかなり差があることが分かった。 $\mathrm{TOCl}$ はクロロホルムの $3 \sim 6$ 倍程度生成しており, これも種類によって相当異なる結果を示した。 $\mathrm{POCl}$ はクロロホルムに皃合ら值（ク口ロホルム生成量 の約 $89 \%$ ）であった。本研究の反応条件では，クロロ ホルム以外の揮発性有機塩素化合物の生成は少ないと 考えられる。本実験と同一の反応条件でフミン酸（和 光純薬製)について反応を行うと， TOCl は770 $\mu \mathrm{g} / 1$, クロロホルムは2 $20 \mu \mathrm{g} / 1$ 生成した。

このよらに，タンパク質と塩素の反応に拈いても， かなり有機塩素化合物を生成することが分かったの で, 次に, タンパク質の主要な構成要素であるアミノ 酸と塩素の反応について検討した。結果はTable 2 の ようになり，アミノ酸の種類によって有機塩素化合物 の生成量は非常に異なることが分かった。

クロロホルムを生成したのは, トリプトファン，チ ロシン，アスパラギンだけであった。トリプトファン はクロロホルムを生成し易いとされている

Table 1 Formation of $\mathrm{TOCl}, \mathrm{POCl}$, and chloroform at the reaction of proteins with clorine in dilute aqueous solution

\begin{tabular}{lccc}
\hline & $\begin{array}{c}\text { TOCl } \\
(\mu \mathrm{g} / 1)\end{array}$ & $\begin{array}{c}\text { POCl } \\
(\mu \mathrm{g} / 1)\end{array}$ & $\begin{array}{c}\text { Chloroform } \\
(\mu \mathrm{g} / 1)\end{array}$ \\
\hline$\alpha$-Casein & 360 & 80 & 90 \\
Hemoglobin & 510 & 140 & 160 \\
Ribonuclease & 470 & 82 & 77 \\
$\beta$-Lactoglobulin & 380 & 77 & 81 \\
Lysozyme & 840 & 150 & 170 \\
$\alpha$-Chymotrypsinogen-A & 600 & 120 & 130 \\
\hline
\end{tabular}

Protein ; $10 \mathrm{mg} / 1$, Chlorine : $20 \mathrm{mg} / 1$

$\mathrm{pH} ; 7, \quad$ Reaction time ; $24 \mathrm{~h}$ 
Table 2 Formation of TOCl, POCl, and chloroform at the reaction of amino acids with chlorine in dilute aqueous solution

\begin{tabular}{lccc}
\hline & $\begin{array}{c}\text { TOCl } \\
(\mu \mathrm{g} / 1)\end{array}$ & $\begin{array}{c}\mathrm{POCl} \\
(\mu \mathrm{g} / 1)\end{array}$ & $\begin{array}{c}\text { Chloroform } \\
(\mu \mathrm{g} / 1)\end{array}$ \\
\hline Alanine & 35 & 34 & $<5$ \\
Valine & $<10$ & $<5$ & $<5$ \\
Leucine & $<10$ & 210 & $<5$ \\
Isoleucine & $<10$ & $<5$ & $<5$ \\
Proline & 66 & $<5$ & $<5$ \\
Hydroxyproline & 630 & $<5$ & $<5$ \\
Phenylalanine & $<10$ & $<5$ & $<5$ \\
Tryptophan & 780 & 65 & 54 \\
Methionine & 83 & $<5$ & $<5$ \\
Glycine & $<10$ & $<5$ & $<5$ \\
Serine & $<10$ & $<5$ & $<5$ \\
Threonine & 54 & $<5$ & $<5$ \\
Cysteine & 37 & 9 & $<5$ \\
Cystine & 52 & $<5$ & $<5$ \\
Tyrosine & 1700 & 32 & 33 \\
Asparagine & 770 & 36 & 7 \\
Glutamine & 22 & 6 & $<5$ \\
Aspartic acid & 1100 & 320 & $<5$ \\
Glutamic acid & 26 & 6 & $<5$ \\
Lysine & 34 & $<5$ & $<5$ \\
Arginine & $<10$ & $<5$ & $<5$ \\
Histidine & 530 & 11 & $<5$ \\
\hline Amino acid & 20 & & $<5$ \\
\hline
\end{tabular}

Amino acid; $10 \mathrm{mg} / \mathrm{l}, \quad$ Chlorine ; $20 \mathrm{mg} / \mathrm{l}$,

$\mathrm{pH} ; 7, \quad$ Reaction time; $24 \mathrm{~h}$

ル基を，チロシンは塩素との反応性が高いフェノール 性水酸基をそれぞれ持っているので，クロロホルムを 生成したと考光られる。アスパラギンについては, 後 述する $\mathrm{pH} 10$ に拈けるアラニンと塩素の反応より類推 して,メチレン基がクロロホルムになると思われる。

クロロホルムを生成しないが, $\mathrm{POCl}$ を生成するア ミノ酸がいくつかあり, ガスクロマトグラム上にはク ロロホルム以外のピークが認められた。ロイシンでは 活性炭に吸着されない形の POCl を生成することが分 かった。これらがどのような化合物なのかは明らかで はなく,さらに検討が必要であろう。

$\mathrm{TOCl}$ の生成は多くのアミノ酸で見られたが，生成 量の大きいアミノ酸は, ヒドロキシプロリン, トリプ トファン, チロシン, アスパラギン, アスパラギン酸, ヒスチジンなどであった。特にチロシンで多く生成し たが，チロシンは前述のよらにフェノール性水酸基を 持っているので，その芳香環が塩素化された化合物が 生成したものと思われる。Pereiraらもそのような化 合物を検出している

以上のように，この実験条件でアミノ酸からも有機
塩素化合物を生成することが分かったが，クロロホル ムの生成について考えると, どのアミノ酸よりもタン パク質の方が生成量が多い。クロロホルムを生成した チロシンやトリプトファンのタンパク質中に占める割 合は数\%にすぎないことを考えると，さらにアミノ酸 よりタンパク質の方がクロロホルムの生成が多いこと になる。

そこで，ペプチド結合を形成するとクロロホルムの 生成量が増大するかどうかを検討するために，数種類 のオリゴペプチドについて同様の実験を行い, Table 3 の結果が得られた。クロロホルムを生成しないよらな アミノ酸より成るオリゴペプチドと塩素の反応では, やはりクロロホルムを生成しないことが分かった。そ れに対して，クロロホルムを生成したチロシンやトリ プトファンのオリゴペプチドでは, クロロホルムの生 成が見られたが，特に，チロシン残基が間に挾まれた バリルーチロシルーバリンで生成量が大きいことが認 められた。バリンはTable 2 に示したようにクロロホ ルムを生成しないことを考旮れば，チロシン残基あた りのクロロホルム生成量はさらに大きいことになる。 
Table 3 Formation of $\mathrm{TOCl}, \mathrm{POCl}$, and chloroform at the reaction of oligopeptides with clorine in dilute aqueous solution

\begin{tabular}{lccc}
\hline & $\begin{array}{c}\text { TOCl } \\
(\mu \mathrm{g} / \mathrm{l})\end{array}$ & $\begin{array}{c}\mathrm{POCl} \\
(\mu \mathrm{g} / \mathrm{l})\end{array}$ & $\begin{array}{c}\text { Chloroform } \\
(\mu \mathrm{g} / \mathrm{l})\end{array}$ \\
\hline Glycyl-leucyl-tyrosine & 580 & 20 & 24 \\
Valyl-tyrosyl-valine & 720 & 100 & 110 \\
Tryptophyl-tryptophan & 680 & 45 & 47 \\
Valyl-tryptophan & 590 & 28 & 30 \\
Glycyl-alanyl-alanine & $<10$ & $<5$ & $<5$ \\
Valyl-leucine & $<10$ & $<5$ & $<5$ \\
Glycyl-glycyl-leucine & 21 & $<5$ & $<5$ \\
Leucyl-leucyl-leucine & 21 & $<5$ & $<5$ \\
Leucyl-phenylalanine & 36 & $<5$ & $<5$ \\
\hline
\end{tabular}

Oligopeptides ; $10 \mathrm{mg} / \mathrm{l}$, $\mathrm{pH} ; 7$,
Chlorine ; $20 \mathrm{mg} / 1$,

Reaction time ; $24 \mathrm{~h}$
測定例が少ないためと, 後述するチロシンと塩素のモ ル比の影響もあるため, 断定はできないが，ペプチド 結合の形成によりクロロホルムの生成が多くなる可能 性があると考学られる。

\section{2 水素イオン濃度の影響}

$\mathrm{pH} 4$ 〜 10 の範囲で $\mathrm{pH}$ を变化させてタンパク質と 塩素の反応を行った結果, 生成したクロロホルムと $\mathrm{pH}$ の関係を Fig 1 に, TOCl と pH の関係を Fig. 2 に 示した。クロロホルムの生成はアルカリ性になるに 従って多くなり，pH7 に対して $\mathrm{pH} 10$ では $2 \sim 3$ 倍程 度大きな生成量を示した。TOCl の生成については, 酸 性側では比較的小さく, $\mathrm{pH} 8.5$ 付近で最大量となるこ とが分かった。

アミノ酸についても同様の実験を行い，その一部に ついて, Fig. 3 扩よび Fig. 4 に示した。アラニンと塩 素の反応では, $\mathrm{pH} 10$ に扔いて著しく大量にクロロホル ムが生成した。佐谷戸らもアラニン濃度 $50 \mathrm{mg} / 1$, 塩素濃度 $200 \mathrm{mg} / 1, \mathrm{pH} 11$ の条件で $4500 \mu \mathrm{g} / 1$ クロロホ ルムが生成するとしている11)。をた，Langheld はアラ ニンと塩素の反応によりアセトアルデヒドを生ずるこ とを指摘して扬り ${ }^{13)}$, アセトアルデヒドはアルカリ性 で塩素と反応するとクロロホルムを生成することが知

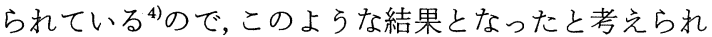
る。その他のアミノ酸でも $\mathrm{pH} 10$ に执いてクロロホル ムの生成量が大きく, Fig. 3 に示した以外のアミノ酸 についても多少生成することが認められた。Fig. 4 に 示したようにアラニンは酸性で $\mathrm{TOCl}$ を汪とんど生 成しなかったが，トレオニン，システイン，グルタミ ン酸などでも同じような結果が得られた。チロシンと アスパラギンでは $\mathrm{pH} 8.5$ に招いて $\mathrm{TOCl}$ の生成量が 非常に大きくなった。プロリン, メチオニン, リシン
などでもこのよらな傾向が見られた。TOClの生成量 の多いアミノ酸が $\mathrm{pH} 8.5$ で $\mathrm{TOCl}$ 生成の極大值を持 つことから,タンパク質の場合も $\mathrm{TOCl}$ 生成が $\mathrm{pH} 8.5$ で極大値を持ったことが理解できる。

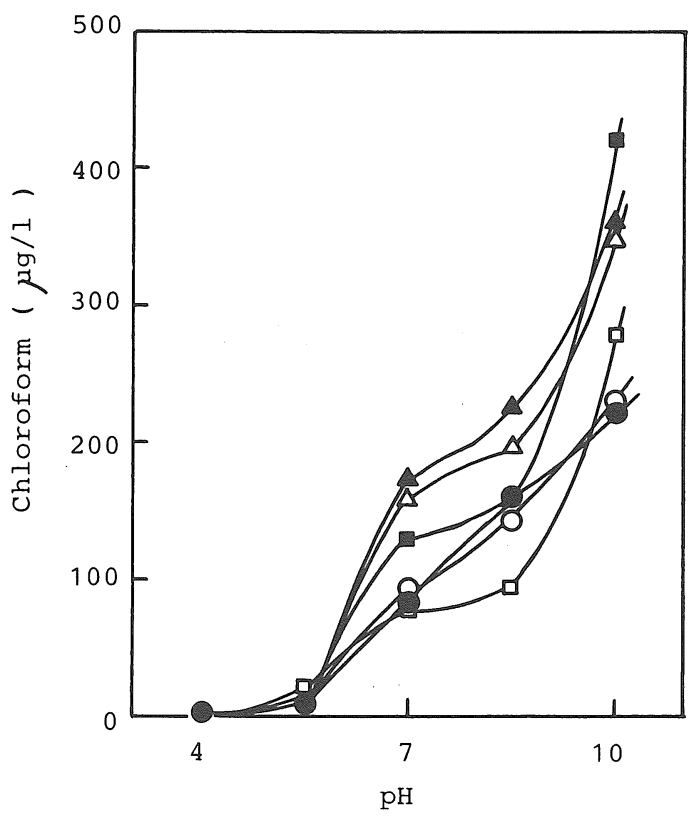

Fig. 1 Influence of $\mathrm{pH}$ on the formation of chloroform at the reaction of protein with chlorine. $\bigcirc$; $\alpha$-Casein $\triangle$; Hemoglobin $\square$; Ribonuclease

; $\beta$-Lactoglobulin $\Delta$; Lysozyme $\alpha$-Chymotrypsinogen $-\mathrm{A}$

Protein; $10 \mathrm{mg} / 1$ Chlorine ; $20 \mathrm{mg} / 1$ Reaction time; $24 \mathrm{~h}$ 


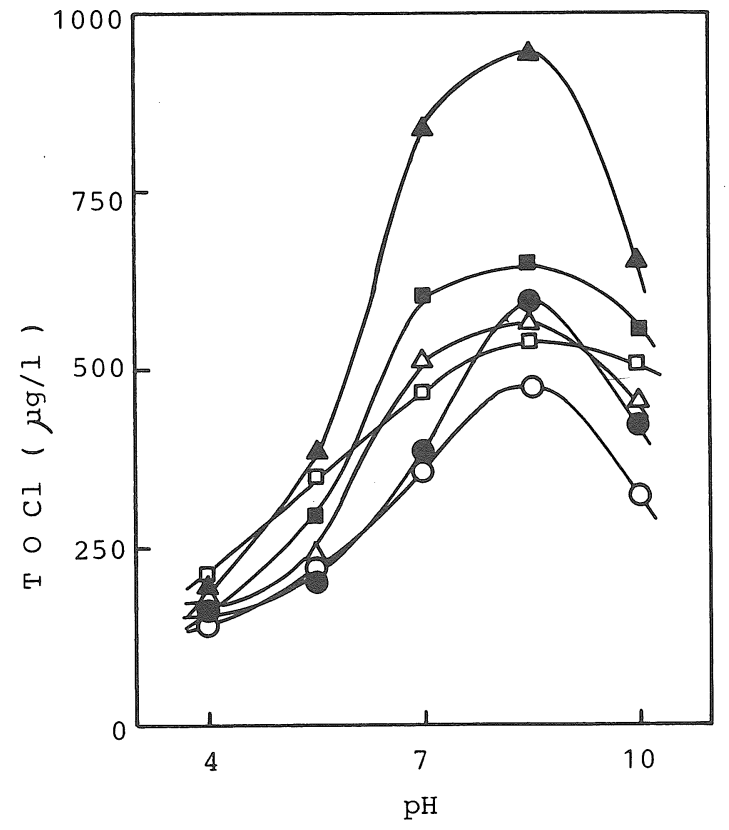

Fig. 2 Influence of $\mathrm{pH}$ on the formation of $\mathrm{TOCl}$ at the reaction of protein with chlorine.

$\bigcirc$; $\alpha$-Casein $\triangle$; Hemoglobin $\square$; Ribonuclease

; $\beta$-Lactoglobulin $\Delta$; Lysozyme $\alpha$-Chymotrypsinogen $-\mathrm{A}$

Protein ; $10 \mathrm{mg} / 1$ Chlorine ; $20 \mathrm{mg} / 1$ Reaction time ; $24 \mathrm{~h}$

\section{3 塩素濃度の影響}

塩素濃度を変化させて $\mathrm{TOCl}$ の生成について検討 した結果, Fig.5のように塩素濃度と TOCl 生成量が 両対数プロットで直線となった。このことは, $\mathrm{TOCl}$ 生 成量が塩素濃度の累乗に比例することを示し，その指 数は $\alpha$ ーカゼインでは 0.17 , チロシンでは 0.53 となっ た。同様の傾向はクロロホルムの生成についても見ら れ, 塩素濃度 $100 \mathrm{mg} / 1$ では $\alpha$ 一カゼインで $120 \mu \mathrm{g} / \mathrm{l}$, チロシンで $150 \mu / 1$ クロロホルムが生成した。

\section{4 タンパク質またはアミノ酸濃度の影響}

タンパク質またはアミノ酸の濃度を $1 \sim 10 \mathrm{mg} / 1$ の 範囲で変えて実験を行った。結果の一例を Fig. 6 拉よ びFig.7に示した。 $\alpha$ 一ガインではクロロホルム抒 よび $\mathrm{TOCl}$ の生成量が共に, $\alpha$ 一カゼインの濃度に対 してほぼ直線的に増加することが分かった。これに対 して, チロシンではチロシンの濃度の増加に伴ない $\mathrm{TOCl}$ の生成量は増加したが, クロロホルムの生成量 は極大值をとることが示された。チロシン $1 \mathrm{mg} / \mathrm{l}$ あ たりのクロロホルム生成量はFig。6 の点線で示した

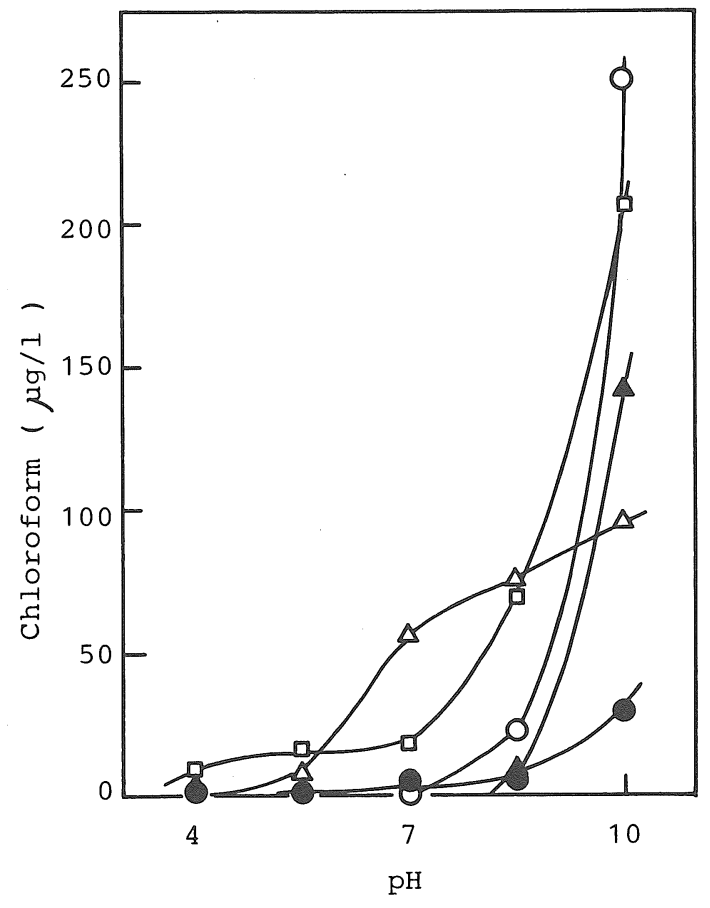

Fig. 3 Influence of $\mathrm{pH}$ on the formation of chloroform at the reaction of amino acid with chlorine.

$\bigcirc$; Alanine $\triangle$; Tryptophan $\square$; Tyrosine O; Asparagine $\mathbf{\Delta}$; Histidine Amino acid; $10 \mathrm{mg} / 1$ Chlorine; $20 \mathrm{mg} / 1$ Reaction time; $24 \mathrm{~h}$

ようになり, 塩素濃度は一定であるので, 塩素とチロ シンのモル比が大きい湆ど単位チロシン量あたりのク ロロホルム生成量は多くなることが分かった。チロシ ンでは芳香環が塩素置換を受け, さらに分解してから クロロホルムを生成するために，クロロホルムを生成 するのに要する塩素が比較的多いと思われるので, こ のような結果が得られたと考兄られ。

\section{5 反応時間の影響}

Fig. 8 に 間とクロロホルム和よび TOCl の生成量の関係を両 対数プロットで示した。良い直線関係が得られており, この場合のクロロホルム拈よび TOCl の生成は反応 時間の累乗に比例すると考光られる。

以上のようなクロロホルム打よび $\mathrm{TOCl}$ の生成に 関する塩素濃度, タンパク質濃度, 反応時間の影響は 他のタンパク質でも同じよらな傾向となった。このこ とからタンパク質と塩素の反応によるクロロホルム抒 よび $\mathrm{TOCl}$ の生成は次式のようになると思われる。

$$
[\mathrm{OCl}]=K[\mathrm{P}][\mathrm{Cl}]^{m} t^{n}
$$




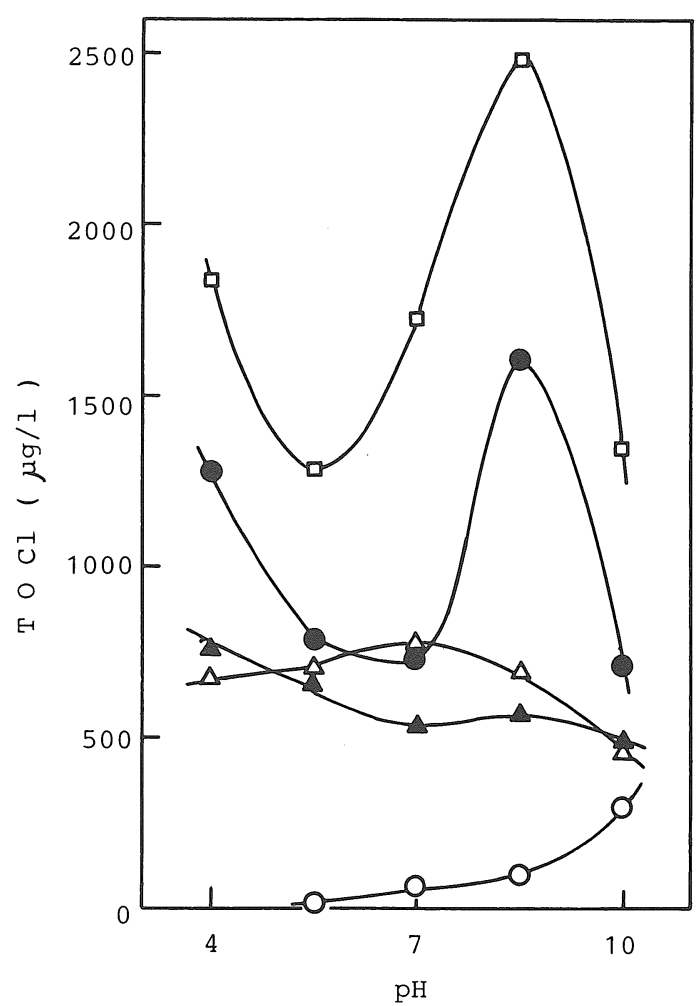

Fig. 4 Influence of $\mathrm{pH}$ on the formation of TOCl at the reaction of amino acid with chlorine.

$\bigcirc$; Alanine $\triangle$; Tryptophan $\square$; Tyrosine

; Asparagine $\mathbf{\Delta}$; Histidine

Amino acid; $10 \mathrm{mg} / 1$ Chlorine; $20 \mathrm{mg} / 1$ Reaction time; $24 \mathrm{~h}$

ここで，[OCl]：生成したクロロホルムまたは $\mathrm{TOCl}$ の濃度,

$[P]$ : 初期タンパク質濃度, $[\mathrm{Cl}]$ : 初期塩 素濃度,

$t$ : 反応時間, $K, m, n:$ パラメーター

この式は, 和田らの研究 ${ }^{14)} に$ 見られるフミン酸と塩 素の反応に拈けるトリハロメタンの生成の式と同じ形 となっている。

\section{4. 結 論}

タンパク質およびその主要な構成要素であるアミノ 酸と塩素の反応を行った結果，以下のことが明らかに なったと考劣る。

1）タンパク質はフミン酸と同程度か, やや小さいク ロロホルム执よび TOCl の生成能を持つ。

2） $\mathrm{pH} 4$ 〜0の範囲で，タンパク質からのクロロホ ルム生成はアルカリ性になるほど多く, $\mathrm{TOCl}$ 生成は $\mathrm{pH} 8$. 5 付近で最も多くなる。汪とんどのアミノ酸にお

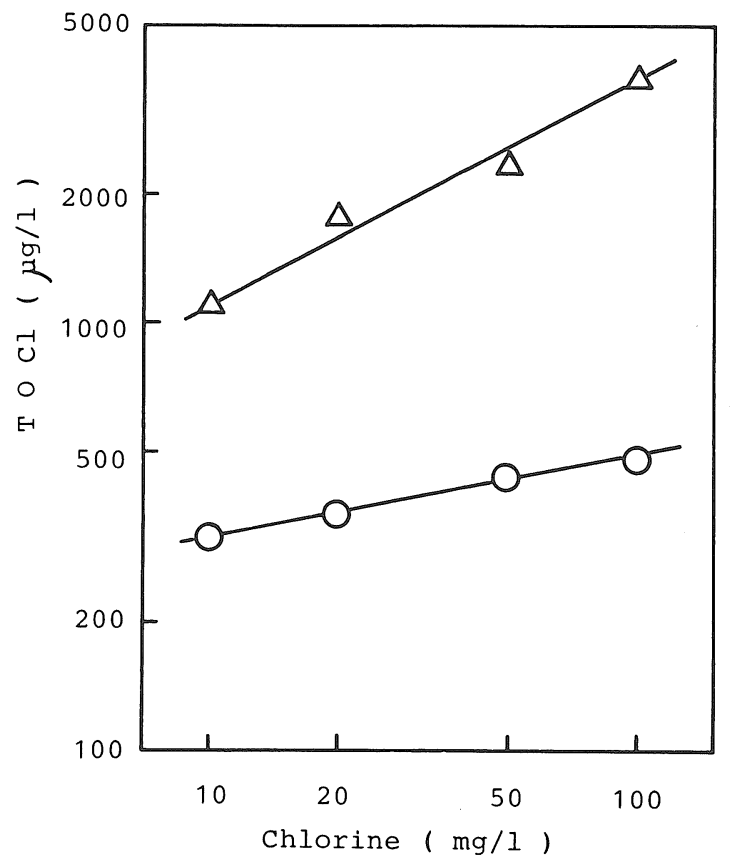

Fig. 5 Relation between chlorine concentration and the amount of $\mathrm{TOCl}$ formed at $\mathrm{pH} 7$.

$\bigcirc ; \alpha$-Casein $\triangle$; Tyrosine

Protein or amino acid; $10 \mathrm{mg} / 1$

Reaction time; $24 \mathrm{~h}$

いてクロロホルム生成はアルカリ性になるほど多く, $\mathrm{TOCl}$ 生成量の多いアミノ酸ではタンパク質の場合と 同様に $\mathrm{pH} 8.5$ 付近に $\mathrm{TOCl}$ 生成の極大値を持つ。

3）タンパク質からのクロロホルムおよび TOClの 生成量は, タンパク質濃度に比例し, 塩素濃度执よび 反応時間の累乗に比例する。

（原稿受理 昭和 58 年 9 月 2 日）

\section{引用 文 献}

1）浦野紘平, 和田洋（1981）水中のトリハロメタン (II)生成反応, 水処理技術, 22, 757-767.

2 ) Rook, J.J. (1974) Formation of haloforms during chlorination of natural waters. Water Treat. Exam., 23, 234-243.

3 ）相沢貴子, 真柄泰基（1982）トリハロメタン生成 特性からみた水質評価（第 2 報）乙尿処理水，水質 污濁研究，5，277-285.

4) Hoehn, R.C., Barnes, D.B., Thompson, B.C., 


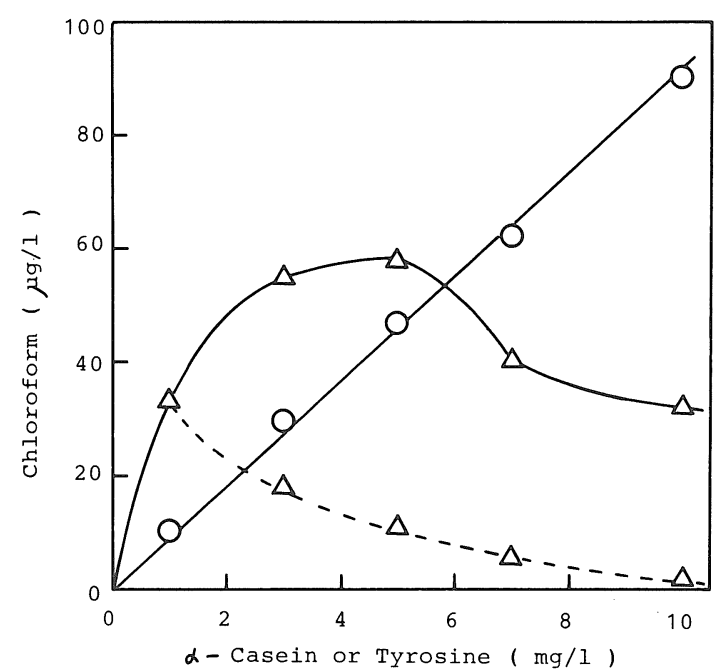

Fig. 6 Relation between protein or amino acid concentration and the amount of chloroform formed at $\mathrm{pH} 7$.

$\bigcirc ; \alpha$-Casein $\triangle$; Tyrosine

Chlorine; $20 \mathrm{mg} / 1$ Reaction time ; $24 \mathrm{~h}$

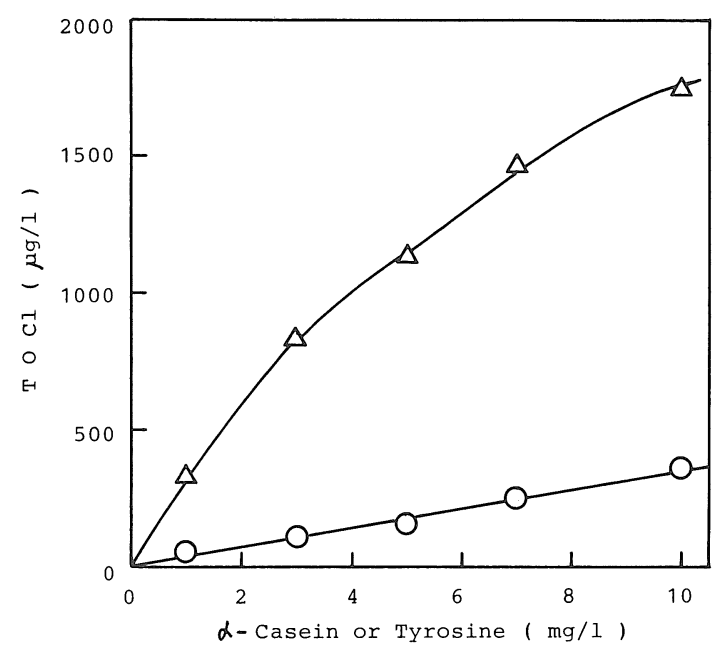

Fig. 7 Relation between protein or amino acid concentration and the amount of $\mathrm{TOCl}$ formed at pH7.

$\bigcirc ; \alpha$-Casein $\triangle$; Tyrosine

Chlorine ; $20 \mathrm{mg} / 1$ Reaction time ; $24 \mathrm{~h}$

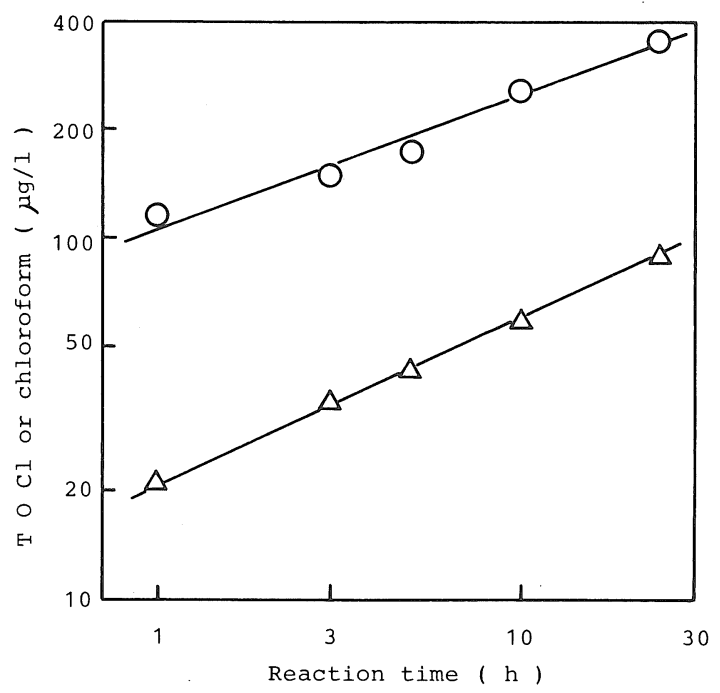

Fig. 8 Effect of reaction time on the formation of $\mathrm{TOCl}$ and chloroform at $\mathrm{pH} 7$.

$\bigcirc$; TOCl $\triangle$; Chloroform

Protein ; $10 \mathrm{mg} / 1$ Chlorine ; $20 \mathrm{mg} / 1$

Randall, C.W., Grizzard, T.J., and Shaffer, P.T.B. (1980) Algae as sources of trihalomethane precursors. J.Am. Water Works Assoc., 72, 344-350.

5 ) Crane, A.M. (1980) Volatile halocarbon production from the chlorination of marine algal byproducts, including D-mannitol. Environ. Sci. Technol., 14, 1371-1374.

6 ）福島博, 相沢貴子, 真柄泰基（1981）藻類による トリハロメタン前駆物質の生成一培養時期と前駆物 質, 水質污濁研究, 4, 229-235.

7 ) Glaze, W.H., and Henderson, J.E. (1975) Formation of organochlorine compounds from the chlorination of a municipal secondary effluent. $J$. Water Poll. Control Fed., 47, 2511-2515.

8 ) Jekel, M.R., and Roberts, P.V. (1980) Total organic halogen as a parameter for the characterization of reclaimed waters: measurement, occurrence, formation, and removal. Environ. Sci. Technol., 14, 970-975. 
9) Pereira, W.E., Hoyano, Y., Summons, R.E., Bacon, V.A., and Duffield, A.M. (1973) Chlorination studies II the reaction of aqueous hypochlorous acid with $\alpha$-amino acids and dipeptides. Biochimica et Biophysica Acta, 313, 170-180.

10）澤村良二（1979）塩素の反応性と生物作用, 変異 原之毒性，7，38-52.

11）佐谷戸安好，中室克彦，松井啓子（1982）低沸点 有機塩素化合物の生成機構に関する研究(III) フミン 酸の塩素処理によるクロロホルムおよびクロロピク リンの生成機構について，水質污濁研究，5，127一 134 .

12）濱田昭，富田基郎（1979）塩素処理による低沸点 有機塩素化合物の生成, 変異原之毒性, 7, 53-64.

13) Langheld, K. (1909) Über das verhalten von $\alpha-$ aminosäuren gegen natriumhypochlorit. Ber., 42, $2360-2374$.

14）和田洋, 浦野紘平（1981）水中の有機物質と塩素 との反応によるトリハロメタン生成速度，第15回日 本水質污濁研究会年次学術講演会講演集, 104-105. 